\title{
Cod and climate in a latitudinal cline: physiological analyses of climate effects in marine fishes
}

\author{
Hans-O. Pörtner*, Christian Bock, Rainer Knust, Gisela Lannig, Magnus Lucassen, \\ Felix Christopher Mark, Franz Josef Sartoris
}

Alfred-Wegener-Institut für Polar- und Meeresforschung, Physiologie mariner Tiere, Postfach 120161 , 27515 Bremerhaven, Germany

\begin{abstract}
Characteristics of temperature-dependent metabolic adaptation, as well as their implications for climate-dependent energy budgets, biogeography and fitness are reviewed and analysed for populations of Atlantic cod Gadus morhua in relation to findings in other fish species from northern and southern hemispheres, especially various species of eelpout (Zoarcidae). The analysis builds on the recently posited concept of oxygen- and capacity-dependent thermal tolerance in aquatic ectotherms. Mechanistic physiological studies are used to explain both functional differences between populations and current observations (such as the northward movement of cod, or the changes in seasonal abundance of eelpout due to global warming). Available data support the hypothesis that natural selection favours individuals that maximize growth and energy efficiency at the expense of ranges of thermal tolerance. The levels of energy turnover are subject to the constraints of resource availability and temperature variability. Temperature variability in the cold, such as in the sub-Arctic, causes a rise in maintenance costs at the expense of growth, but possibly in favour of motility, and thus of foraging capacity. These different trends are mirrored in higher capacities for gene expression of key enzymes involved in aerobic metabolism (during cold acclimation) in northern as compared to southern cod populations of the East Atlantic. However, detailed patterns, as well as many of the underlying mechanisms, remain underexplored, especially with respect to the suggested hierarchy of energy allocation to energy budget components.
\end{abstract}

KEY WORDS: Acclimation · Body size $\cdot$ Climate sensitivity $\cdot$ Cod $\cdot$ Eelpout $\cdot$ Growth $\cdot$ Oxygen limitation $\cdot$ Population $\cdot$ Thermal tolerance

\section{ECOLOGICAL IMPACTS OF CLIMATE CHANGE: THE ROLE OF SPECIES-SPECIFIC THERMAL WINDOWS}

Climate variability has long been seen to influence the structure and functioning of marine, terrestrial and freshwater ecosystems. Fluctuations in marine communities and populations have been attributed to the impact of decadal-scale variations in the coupled ocean-atmosphere system (Cushing 1982, Beamish 1995, Bakun 1996, O'Brien et al. 2000, Finney et al. 2002). Accordingly, ongoing climate change is projected to affect individual organisms during all life stages, populations, communities, and the composition and functioning of ecosystems. The effects of climate change are direct, e.g. through changing water temperatures, changes in sea level, in hydrodynamics, and in the wind and storm regime, or it is indirect, e.g. through changes in the composition of the food chain.

The Intergovernmental Panel on Climate Change (IPCC 2001, 2007) has developed a climate scenario for Europe as predicted by different climate models. Over the next decades, winters classified as cold (currently occurring during 1 in 10 yr) will become less frequent by the 2020s, and will almost disappear during the next 80 yr. 'Ice winter disturbances' will be less abundant in the southern North Sea, while the frequency of hot summer events will increase. In 2080 nearly every summer will be hotter than the 1-in-10 summers defined as hot under present climate conditions. 
During the next 90 to $100 \mathrm{yr}$, models also predict an increase in sea surface temperatures (SSTs). Sheppard (2004) expects an increase of about 1.67 to $2.98^{\circ} \mathrm{C}$ between 2000 and 2099 for the northern sections of the North Sea. For the shallower southern North Sea, an increase of 3.06 to $3.84^{\circ} \mathrm{C}$ may result. A comparable scenario was developed for the Baltic Sea, with an increase in SST of about $2.3^{\circ} \mathrm{C}$ (Meier 2002) and the highest increments of 2.5 to $2.7^{\circ} \mathrm{C}$ in winter and spring (December to May). During the last 40 yr, water temperatures at Helgoland Roads have already increased by $1.13^{\circ} \mathrm{C}$, and cold winters (SST around $-1^{\circ} \mathrm{C}$ ) occurred about once every $10 \mathrm{yr}$ up to 1944 , but have only occurred once since 1960 (Wiltshire \& Manly 2004). Continued warming will be accompanied by globally rising sea levels (13 to $68 \mathrm{~cm}$ by 2050) and by an increased frequency of weather extremes, including storm events.

The shift in the water temperature regime is one of the main driving forces currently causing changes in species abundance and in species composition of ecosystems, especially in coastal waters. Examples can be found among invertebrates (Southward et al. 1995, Kröncke et al. 1998) and fishes (Perry et al. 2005, Pörtner \& Knust 2007, see also von Westernhagen \& Schnack 2001 and literature cited therein). For pelagic fishes in general and for commercial fish species like cod Gadus morhua many studies focus on the relationship between climate condition and stock or population size and structure (e.g. Pepin et al. 1997, Otterlei et al. 1999, Brander \& Mohn 2004, Ottersen et al. 2006, Stige et al. 2006, Takasuka et al. 2007, 2008). Conclusions from these studies are mainly based on statistical relationships between, e.g. recruitment, spawning events and water temperature (e.g. Fig. 1); between stock size and climatic indices like the North Atlantic Oscillation (NAO); or the statistical relationship between factors like the seasonal timing of spawning in relation to the timing of phyto- and zooplankton production. However, without a mechanistic understanding of effective principles, consensus on the ecological impacts of climate change remains elusive (Jensen 2003, Parmesan \& Yohe 2003, Pörtner \& Knust 2007, Drinkwater et al. in press). A comprehensive cause and effect understanding also requires an understanding of how mechanisms interact across levels of biological organisation, between molecule and ecosystem (Pörtner 2002a,b).

Atlantic cod Gadus morhua is one key species presently affected by the warming trend, e.g. in eastern Atlantic waters (e.g. Perry et al. 2005). Cod is a typical inhabitant of the continental shelf, is of major importance to fisheries and is characterized by northern and southern distribution limits in the North Atlantic. The present study aims to review and analyse the character-

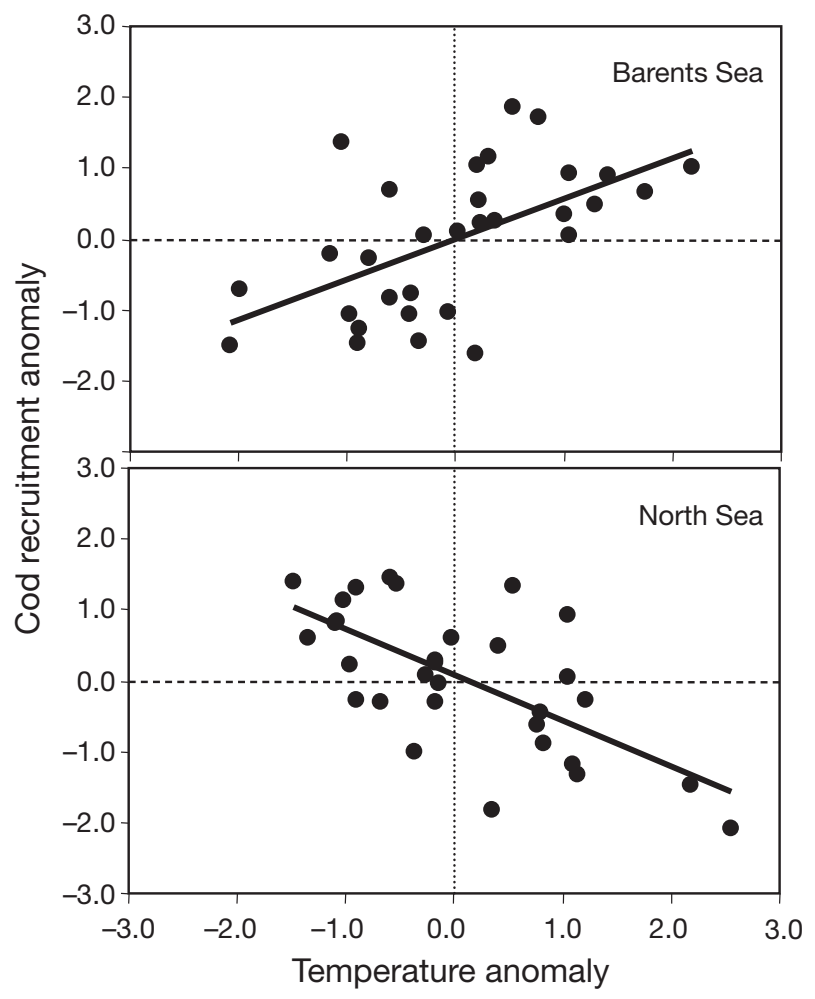

Fig. 1. Gadus morhua. Cod recruitment success and environmental temperature over time in the Barents and North Seas. The North and Barents Sea temperatures are close to the upper and lower ends of the thermal tolerance window of this species, respectively (based on data by Sirabella et al. 2001). The correlation likely emphasizes the role of optimal spawning temperatures within the thermal window of the species (cf. Takasuka et al. 2008 and Section 2)

istics of temperature-dependent metabolic adaptation, as well as their implications for climate-dependent energy budgets, biogeography and fitness in populations of Atlantic cod along a climate gradient between the North Sea and the Arctic. Our interpretation builds on the recent concept of oxygen- and capacity-dependent thermal tolerance in aquatic ectotherms (Pörtner 2001, $2002 a, b)$ and on findings in other fish and invertebrate species. In relation to this, we consider the energetics of temperature adaptation in stenotherms versus eurytherms from various latitudinal clines in northern and southern hemispheres. We also draw on complementary information from another eurythermal species, the common eelpout Zoarces viviparus, as a typical nonmigratory inhabitant of shallow areas of the coastal zone. Cod shows an r-selective reproduction strategy, which supports its large-scale distribution in the North Atlantic through drifting eggs and larvae. Eelpout display a k-selective reproduction strategy, associated with low rates of dispersal (due to vivipary and the production of benthic juveniles). Both species have a boreal distribution. The southernmost distribution limit 
for eelpout is found in the Wadden Sea, a section of the southern North Sea, and, for cod, in the northern part of the Bay of Biscay (Whitehead et al. 1994).

Changes in temperature maxima or minima, more than in mean temperatures, represent significant driving forces for changes in population structure and the community composition of marine areas (Stachowicz et al. 2002, Stenseth \& Mysterud 2002), with larger changes and effects at high latitudes (Root et al. 2003). Extreme winter events (water temperatures that are greatly reduced over extended time periods, as compared to long-term means) drive changes occurring in ecosystem such as the German Wadden Sea (Armonies et al. 2001). Winter exposure of fish larvae to low temperatures is seen as a key selective factor (Hurst \& Conover 2002). In general, cold stress is likely effective in setting temperature-dependent biogeography and possibly biodiversity (Roy et al. 1998). Alleviation of winter cold will accordingly have its specific effects. However, the same is true for the parallel increase in the occurrence of warmer summers (Pörtner \& Knust 2007). Observed shifts in geographical distribution (Perry et al. 2005) in species composition and in the population structure of different species may be explainable by the shifting frequencies of these extreme weather conditions, as has already been observed in the past for periods of 'warmer winters' (Cushing 1975).

These general considerations indicate specialisation of marine fauna and their different life stages for climate-related temperature windows as one global reason for the sensitivity of marine fauna to temperature extremes and for associated processes on an ecosystem level (Pörtner \& Knust 2007). This clearly requires an understanding of the physiological background of thermal specialisation, or, in other words, an understanding of why animals are restricted to limited thermal environments. Further down the line, the question needs to be asked how the degrees of thermal specialisation, as well as potential differences between life stages, influence the key processes shaping population size and structure, i.e. fecundity, growth and mortality. All of these are related to the levels of organismal performance and fitness (i.e. the capacities to forage, migrate, grow, or reproduce), which, in turn, are influenced by temperature (Pörtner \& Knust 2007). At the next level of biological organisation, i.e. the ecosystem, we have to ask how the existence of different thermal windows of species interacting in an ecosystem influences the quality and intensity, as well as the seasonal timing, of their interactions.

The recruitment success of Atlantic cod clearly depends upon the climate regime as shown in Fig. 1. The figure compares anomalies of recruitment and SST during spring for cod Gadus morhua from the North Sea (NSC) and the Barents Sea (northeastern Arctic cod =
NEAC). NEAC recruitment decreases during cooling periods and increases upon warming, whereas NSC recruitment displays the opposite trend; it is reduced upon warming, but rises during cooling (see also O'Brien et al. 2000). These findings are supported by Stige et al. (2006), who show clear effects of the NAO index on cod recruitment, with significantly larger effects at the southern and northern borders of the geographical distribution area of cod. In consequence, a significant positive relationship results between warmer water temperature and improved recruitment results for NEAC, whereas an inverse relationship results for the same (warmer) years for NSC (Planque \& Frédou 1999, Dippner \& Ottersen 2001, Sirabella et al. 2001). These trends clearly indicate that, according to reproductive performance, NSC lives close to the upper, and NEAC to the lower, thermal limits of the species.

As a consequence, temperature defines the southern distribution limits of NSC and the northern distribution limits of NEAC, and the respective temperature regimes would delineate the upper and lower borders of the thermal window of recruitment of the species. The relationships between spring water temperature and recruitment may reflect thermal influences on the condition of the (spawning) adults (cf. Pörtner et al. 2001), on the thermal sensitivity of eggs and larvae, or on the seasonal timing of food availability for larvae and juveniles. The recent field data collected by Takasuka et al. $(2007,2008)$ confirm that direct effects of warming on individual growth and on the capacities for gamete production, gamete quality and spawning by the mature adults would play a key role in positive as well as negative climate impacts on individual fish species, even without intermediary effects through the food web. Temperature-dependent differences in organismic performance windows may even cause regime shifts, such as from sardines to anchovies in the Japan Sea upon recent warming (Takasuka et al. 2007, see below).

The eelpout Zoarces viviparus provides a further example of the relevance of thermal windows of performance in shaping ecosystem changes. The temperature dependence of recruitment success in eelpout is not known; however, eelpout relative abundance and growth performance shows a significant dependence on water temperatures in summer (Fig. 2). In the Wadden Sea area of the East Frisian Islands, abundance is reduced in those summers with high mean water temperatures (Pörtner \& Knust 2007), in the same temperature range in which growth performance decreases. This low abundance is associated with the disappearance of mainly large individuals at upper thermal limits. Low abundance is paralleled by a loss in performance and a significantly higher mortality of this non-migratory species in hot summers. 
Other evidence is more indirect. For example, Beentjes \& Renwick (2001) tested the abundance (landings) of red cod Pseudophycis bachus against 34 environmental variables and found that correlations were strongest between commercial catch and SST. Similar observations have been made in terrestrial organisms (higher plants, insects, birds). Here, climate effects on biogeography and biodiversity are independent of the position of the species in the food chain (Huntley et al. 2004), indicating constraints at the level of the individual species and organisms. Thermal windows are thus decisive in shaping biogeography, a concept that warrants further analyses in aquatic ecosystems. Furthermore, temperature-dependent windows of growth performance may differ, not only between species, but even between populations or developmental stages of a species (Pörtner et al. 2001, 2005a,b).

It should be noted here that there is a long standing debate in fisheries biology over factors shaping population dynamics and biomass. In the past, the 'bottleneck' of recruitment was in fact mainly discussed in the light of survival conditions for eggs and larvae (e.g. Bartsch \& Knust 1994a,b). The match-mismatch phenomena between food availability and food demand of early life stages are modified by the mortality of larvae and early juveniles due to predation. However, in most cases, the analysis is focused on statistical relationships (e.g. phytoplankton biomass versus abundance of cod larvae; Brander 1994), but there is a need for mechanism-based explanations (Drinkwater et al. in press). In cod, the relationship between spawning stock biomass (SSB) and recruitment appears to be weak (Ottersen \& Sundby 1995, Marshall et al. 2000). In addition, SSB is an inadequate measure of the reproductive potential of a fish stock; population fecundity parameters like total egg production and the condition of the eggs have to be taken into account (e.g. Mukhina et al. 2003, Ottersen et al. 2006). Accordingly, recruitment success (number and fitness of offspring) is linked to fecundity of the parent population and thus depends on the reproductive potential of individual fish within the spawning stock (Rothschild 1986, Kjesbu et al. 1996, Ulltang 1996, Trippel et al. 1997, Marshall et al. 1998). This already indicates that fecundity (number of spawned eggs) and the fitness (condition) of eggs are related to condition and fitness of the adults (i.e. the available energy for reproduction).

Changes in water temperature and food availability have in fact been observed to cause variations in the fecundity of cod (Kjesbu et al. 1998). For Norwegian coastal cod and the north-eastern Arctic cod, Otterlei et al. (1999) found faster larval development and increasing growth rates of juveniles (which reduce larval and juvenile mortality by predation) between 4 and $14^{\circ} \mathrm{C}$. The development of eggs and the first larval stages are thus related to the fitness of the adults, and the development of all life stages, including the growth rates of juveniles, are related to the temperature regime. This insight must be considered when interpreting characteristics of each population and of differences between populations of cod and eelpout (cf. Pörtner et al. 2001).

The present analysis builds on the hypothesis that the physiological principles shaping the success, and thermal windows, of different life stages are identical or similar for all stages. Significant progress has been made in recent years in understanding the physiological underpinning of fitness characters, as well as the climate-related displacement of functional characters between populations and species. Fig. 2 illustrates the relevance of integrated ecological and physiological approaches for an understanding of these patterns (Parsons \& Lear 2001, Pörtner et al. 2001). Emerging insight also suggests that, while climate-dependent physiological principles are likely identical or similar across life stages, specific functional implications result, for example, between juveniles and adults. The principles and some of these implications will be elaborated on in this study.

\section{PHYSIOLOGICAL BACKGROUND}

The ecological phenomena reported above lead to important questions from a physiological point of view: (1) Why do animals specialize on thermal windows? (2) What are the functional consequences of differing breadths of thermal windows? (3) What are the functional consequences of the differing and variable position of thermal windows on the temperature scale? Recently, a wider comparison of the mechanisms characterizing thermal intolerance between and within species of marine invertebrates and fish led to the general concept that limitations in the capacity of oxygen supply and distribution to tissues characterizes the first line of thermal intolerance in animals (Pörtner 2001, $2002 a, b)$. Deviations from an optimum temperature of an individual will, beyond thermal limits, induce a progressive mismatch between oxygen supply and oxygen demand, which will, in turn, firstly cause a decrease in whole-organism performance and finally become lethal towards extreme temperatures. Molecular and cellular functioning integrate into the thermal window of the organism and shape performance characters of a species or population (cf. Pörtner et al. 2005a, Pörtner \& Knust 2007).

Evidence for oxygen- and capacity-limited thermal tolerance initially arose from observations of low and high temperature thresholds in marine invertebrates and fish, defined as critical temperatures $\left(T_{\mathrm{c}}\right)$, which are associated with the transition to anaerobic mito- 


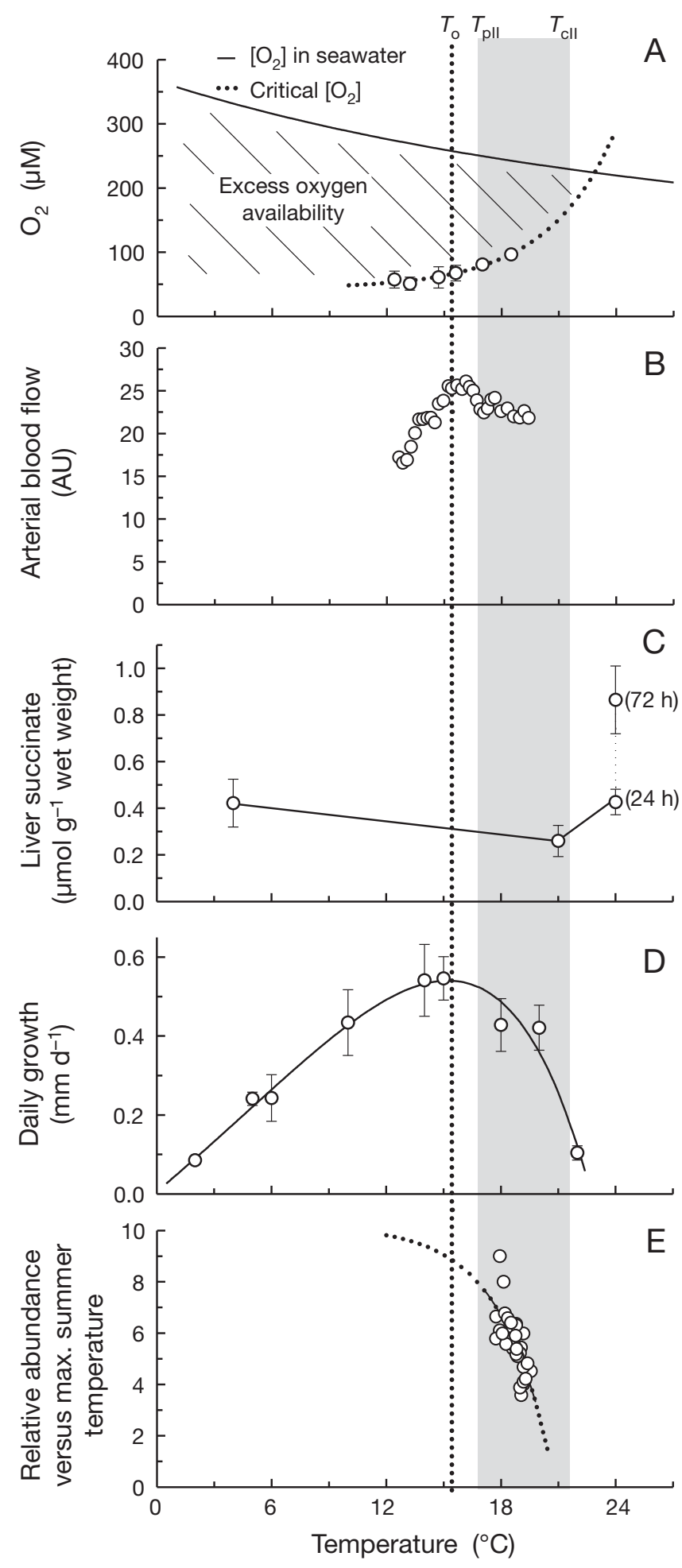

chondrial metabolism due to failing oxygen supply in extreme cold and warmth (for review see Pörtner 2001, 2002a). Specifically, heat limitation in eelpout (temperate Zoarces viviparus, Antarctic Pachycara brachycephalum) and Atlantic cod Gadus morhua begins with a limitation in oxygen supply capacity
Fig. 2. Zoarces viviparus. Eelpout thermal limitation and the respective functional and ecosystem consequences for the German Wadden Sea population (after Pörtner \& Knust 2007). (A) Scope of aerobic metabolism (shaded area), $\mathrm{O}_{2}$ concentration in sea water (solid line) and critical oxygen concentration (open circle fitted by broken curve) in relation to water temperature. Data were recalculated from Zakhartsev et al. (2003) for a water salinity of $32 \%$. (B) Arterial blood flow in relative units versus temperature measured by nuclear magnetic resonance imaging techniques. Values (open circles) depict running means (mean width $=15$ ). Data recalculated from Pörtner et al. (2004). (C) Succinate concentration in the liver versus water temperature; mean values $( \pm \mathrm{SD}$, after $24 \mathrm{~h}$ and $72 \mathrm{~h}$ of exposure to heat). Redrawn from Van Dijk et al. (1999). (D) Daily growth increment in relation to water temperature. Data recalculated from Fonds et al. (1989). (E) Summer water temperatures versus relative abundance of eelpout in the East Frisian Wadden Sea, southern German Bight (5 yr running mean, recalculated from data by Tiews 1983, Tiews \& Wienberg 1990). The development of water temperature over time for the Wadden Sea area was calculated from data provided by the Deutscher Wetterdienst (German Weather Service). The negative correlation between water temperature and abundance reflects high mortality of especially larger eelpout in those years with higher summer temperatures. The optimal temperature $T_{\mathrm{o}}$ is found at around $15^{\circ} \mathrm{C}$. At this temperature, growth rate (Panel D) is highest, combined with high aerobic scope (Panel A) at maximized resting circulatory oxygen supply (Panel B). Oxygen availability decreases between the upper pejus temperature $T_{\mathrm{pII}}$ and the upper critical temperature $T_{\text {cII }}$ (Panel A) in response to a saturated and then decreased resting arterial blood flow (Panel B) and finally leads to increased levels of anaerobic metabolic end products (Panel C). The progressive decrease in aerobic scope in the pejus range parallels the falling growth rate (Panel D) and the drop in relative abundance (Panel E). The upper critical temperature $T_{\text {cII }}$ as determined according to Panels B and C (Van Dijk et al. 1999, Pörtner et al. 2004), is reached between 22 and $24^{\circ} \mathrm{C}$, where the critical oxygen concentration reaches the oxygen concentration in seawater, according to the extrapolated curve (Panel A)

(Zakhartsev et al. 2003, Lannig et al. 2004; Figs. 2 \& 3), which leads to anaerobic metabolism, as indicated by the depletion of high energy phosphates and the onset of mitochondrial succinate formation and accumulation (e.g. Van Dijk et al. 1999, Mark et al. 2002, Pörtner et al. 2004). Van Dijk et al. (1999) and Zakhartsev et al. (2003) identified critical temperatures of 22 to $23^{\circ} \mathrm{C}$ in eelpout, below the classical critical thermal maxima defined by the onset of spasms. However, in the field, significantly enhanced mortality, and thus thermal limitation, occurred even below the upper critical temperatures (Fig. 2). Moderate decreases in aerobic scope and performance are thus sufficient to cause a loss in fitness and enhanced mortality (Pörtner \& Knust 2007). The onset of oxygen limitation and associated performance decrements occurs on both sides of the thermal window, at both upper and lower pejus temperatures (pejus $=$ worse), before critical temperatures are 

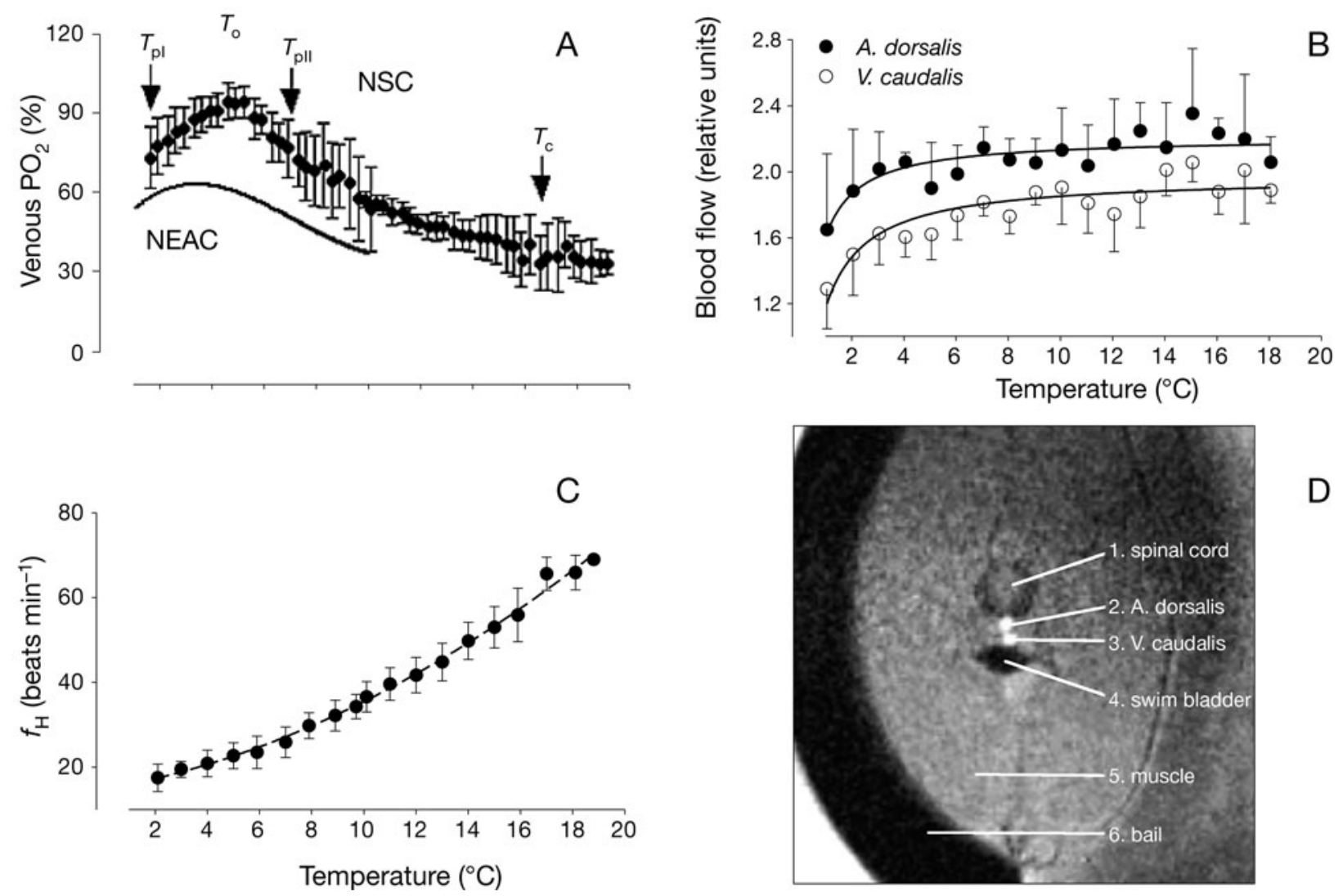

Fig. 3. Gadus morhua. (A) Relative (\%) changes in venous $P_{\mathrm{O} 2}\left(P_{\mathrm{VO} 2}\right)$. Changes in $P_{\mathrm{VO} 2}$ were measured in the ductus Cuvier of North Sea and northeast Atlantic cod (NSC and NEAC, respectively), starting from an acclimation (control) temperature of $10^{\circ} \mathrm{C}$ (data expressed as percent fractions of the highest $P_{\mathrm{O} 2}$ values). Arrows indicate the optimum temperature range ( $\left.T_{\mathrm{o}}\right)$, with highest $P_{\mathrm{VO} 2}$ values bordered by putative pejus temperatures ( $T_{\mathrm{pI}}$ and $\left.T_{\mathrm{pII}}\right)$ (based on data by Sartoris et al. 2003, Lannig et al. 2004). These identify the temperatures beyond which $P_{\mathrm{VO} 2}$ values fell significantly below the maximum, causing a reduction in aerobic scope. The upper critical temperature $\left(T_{\mathrm{c}}\right)$ identifies an insufficient oxygen supply during warming that correlates with the onset of arrhythmia and, finally, the collapse of the fish. The preliminary inclusion of mean $P_{\mathrm{VO} 2}$ values for NEAC (G. Lannig unpubl. data) indicates lower venous oxygenation and a lower optimum than in NSC. This finding is in line with a left shift of the thermal window and enhanced tissue oxygen demand and thermal sensitivity of the sub-Arctic population. (B,C) Changes of blood flow (in the aorta dorsalis and vena caudalis) and heart beat frequency $\left(f_{\mathrm{H}}\right)$, respectively, in NSC vs. acutely changing temperature at $1^{\circ} \mathrm{C} \mathrm{h}^{-1}$. (D) A typical flow-weighted magnetic resonance image (axial view) obtained at the anterior end of the pectoral fin under control conditions $\left(10^{\circ} \mathrm{C}\right)$. The intensity of the bright spots reflects the level of blood flow

reached. Pejus temperatures border the temperature window of optimum oxygen supply and, therefore, enable optimal performance, suitable to support successful survival in the natural environment.

While the limitation of both circulatory and ventilatory performance appears responsible for thermal limitation in crustaceans (Frederich \& Pörtner 2000), the respective data in fish suggest that ventilation operates over a wider temperature range than circulation. In rainbow trout Salmo gairdneri, Heath \& Hughes (1973) found that heart rate decreased at temperatures $>24^{\circ} \mathrm{C}$, whereas ventilation remained virtually unchanged until death of the animals occurred. Similarly, Sartoris et al. (2003) suggested that the efficiency of arterial oxygen uptake and thus arterial oxygen tensions remain largely unaffected by progressive warming in fish. Therefore, cardiac rather than ventilatory performance might be more crucial in the thermal limitation of fish. In line with the patterns of temperaturedependent performance of the circulatory system in fish (Farrell 2002), Mark et al. (2002) found circulatory rather than ventilatory limitations at extreme temperatures in Antarctic eelpout. With respect to thermal sensitivity, the capacity of arterial oxygen uptake may thus be in excess of venous oxygen release, thereby supporting a wide thermal window of largely venous oxygen supply to the teleost heart. Accordingly, Lannig et al. (2004) identified a temperature range of optimized venous oxygen supply to the heart of resting NSC (Fig. 3). Beyond this range, progressively inadequate oxygen transport to tissues results, mirrored in insufficient levels of blood and/or tissue oxygenation in relation to oxygen demand. All of these findings suggest capacity-limited thermal tolerance according 
to optimized oxygen supply within a limited thermal window in fish, in line with the respective data in other marine phyla (Pörtner 2001).

Molecular and cellular mechanisms (e.g. enzyme and membrane structure, ion and $\mathrm{pH}$ regulation, RNA/ DNA synthesis, protein biosynthesis capacities, etc.) are involved in setting functional capacities of cells, tissues and the organism and are adjusted to operate within the same temperature range, however, in wider windows than the whole organism. Thermal limitation becomes visible first at the highest level of biological organisation and integration of these mechanisms, in the organism, through the onset of limited aerobic scope (cf. Pörtner 2002a).

In the eelpout, high pejus temperatures of around $18^{\circ} \mathrm{C}$ delineate the onset of a decrease in growth performance and in field abundance (Fig. 2). Under field conditions, loss of aerobic scope $\left(>18^{\circ} \mathrm{C}\right)$ and associated loss of performance capacity thus appear crucial in limiting survival during hot summers. Abundance collapses towards $21^{\circ} \mathrm{C}$ in the field (Fig. 2E) before the limits of passive survival are reached at temperatures $>22^{\circ} \mathrm{C}$ (Fig. 2C,D). In general, the physiological data provide clear evidence for the thermal specialisation of water-breathing animals - most importantly through the specialisation of oxygen supply mechanisms and associated tissue, cell and molecular functions - to a limited temperature range. These data also indicate that the eelpout operates at the limits of its acclimation capacity in the Wadden Sea, meaning that the species has no capacity left to shift upper thermal limits to higher temperatures, and is existing at its temperature-dependent distribution limit set by summer extreme temperatures.

Predominant loss of large eelpout individuals in the warmth confirms expectations from allometry, in that, a larger body size enhances thermal sensitivity - i.e. oxygen supply becomes restricted earlier than in smaller specimens. When transferring this insight to Atlantic cod, such a relationship between body size and temperature and limited oxygen supply can also be seen in the influence of body size on temperaturedependent growth rates (Fig. 4). The general principles of oxygen- and capacity-limited thermal tolerance support the following interpretation. Within each size class and in relation to the size-specific growth maximum, the data show a loss in growth performance upon warming and upon cooling beyond optimal temperatures. In the warmth, this relative decrement is induced by oxygen limitation (cf. Fig. 2), which develops earlier (at lower temperatures) in larger than in smaller fish. As a consequence, growth optima are found at lower temperatures in larger fish. The downward shift in growth optima (from $14.8^{\circ} \mathrm{C}$ in $4 \mathrm{~g}$ fish down to $10.3^{\circ} \mathrm{C}$ in $2.2 \mathrm{~kg}$ fish) thus reflects the fact that upper heat limits (both pejus and critical) shift to lower temperatures with increasing body size. At the low end of the thermal window, a shift of cold limits with increasing body size (to higher temperatures in this case) is not as obvious. Growth is reduced upon cooling for kinetic reasons, and all fish still display positive growth close to $0^{\circ} \mathrm{C}$. Cold tolerance, therefore, appears to be relatively similar between size classes. Overall, the earlier drop in relative growth of larger fish upon warming confirms that the thermal window of cod shrinks with increasing body size.

As mentioned above, a general question associated with these findings is why animals are constrained to limited thermal windows. The benefits and limits of thermal specialisation can be understood through the trade-offs and constraints involved in the thermal adaptation of key molecular-to-organismal mechanisms associated with functional capacity and aerobic scope. These become visible when temperature-dependent physiological characters are compared in closely related congeneric species adapted to various temperature regimes (Pörtner 2001, 2002a,b, Hochachka \& Somero 2002). However, permanent physiological differences induced by temperature and climate even develop in populations of the same species in a latitudinal cline; these result in population-specific patterns of oxygen-limited thermal tolerance (Sommer et al. 1997, Sommer \& Pörtner 1999, 2002, 2004, Pörtner 2001, Pörtner et al. 2005a,b, Wittmann et al. 2008, this Special). As a correlate of functional specialisation within a limited thermal window, isozyme composition and the latitudi-

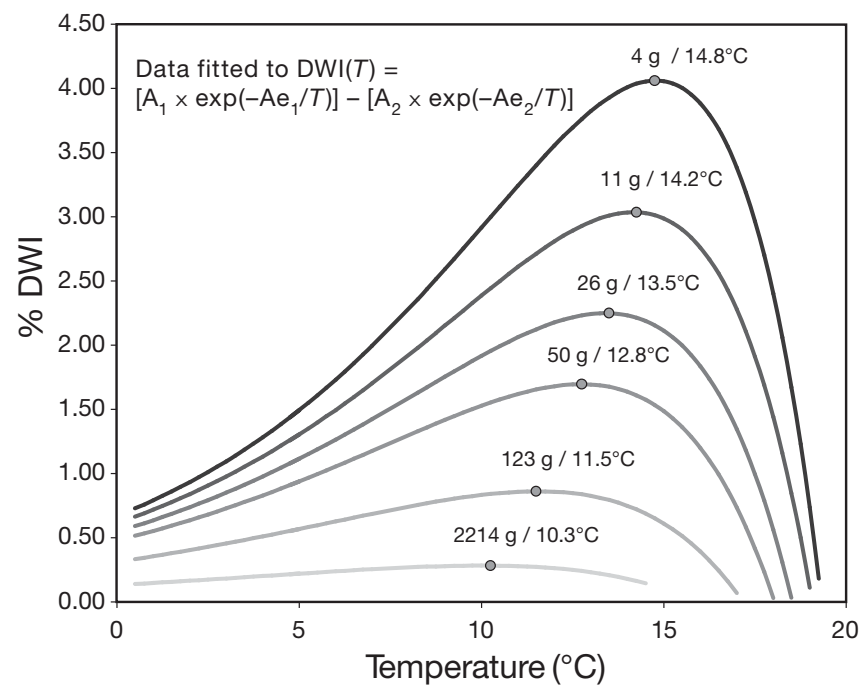

Fig. 4. Gadus morhua. Thermal windows of growing cod (based on data by Björnsson \& Steinarsson 2002). Note a trend for the narrowing of thermal windows as optimal temperatures and upper heat limits are reduced with increasing body size. DWI: daily weight increment, $T$ : temperature; A1, Ae1, A2, Ae2: numerical constants, numerical coefficients 
nal temperature shift were clearly interdependent in the lugworm Arenicola marina (Hummel et al. 1997). Differentiation between populations is supported by the use of distant spawning grounds and is thus manifest in genetic differences (Hummel et al. 1997, Nielsen et al. 2001). In Atlantic cod populations following the north-south cline, the Hb-I(1/1) allele displays an increasing frequency towards the south. This leads to a higher $\mathrm{O}_{2}$ affinity at higher temperatures and thereby safeguards oxygen transport in the warmth (Brix et al. 1998, 2004, Colosimo et al. 2003). Furthermore, growth rate maximization within a thermal window may depend on genotype-dependent oxygen affinity (Brix et al. 1998). These findings may indicate that blood oxygen transport is optimized to within the range of thermal specialisation.

Consistent and permanent physiological differences between populations of a species, according to shifting climate conditions in a latitudinal cline, mirror the different thermal windows of the respective populations as a result of micro-evolutionary adaptation to regional climate conditions. Such functional differences should provide access to the driving forces of thermal specialisation. The sequence of overlapping, but shifted, thermal windows seen among invertebrates and fish along the eastern Atlantic cline strongly suggests that a species can extend its total thermal range by differentiating into populations according to local climates. Populations closest to the border of the overall tolerance window of the species will then experience speciesspecific thermal limits such as those outlined above for the decrease in eelpout abundance in the southern North Sea, or as seen for the collapse of North Sea cod (Fig. 1). The capacities of the 'warmest' population to acclimate or adapt to further warming and of the 'coldest' population to adjust to further cooling are thus clearly limited. Consequently, the widening of the thermal window of a species by differentiation into physiologically distinct populations also remains limited.

The same conclusions likely apply to the thermal specialisation of congeneric marine species in a thermal cline. On evolutionary time scales, these different species may, in fact, have originated from differentiated populations of a common ancestor species. Speciation may have involved thermal specialisation. The resulting closely related species, however, would still be limited in their capacity to extend the thermal range of the genus. While we are not aware of data for congeneric fish species in a latitudinal cline, this conclusion is in line with results obtained in recent studies of 6 closely related species of porcelain crabs (genus Petrolisthes), that live in different thermal microhabitats along the Californian coast (Stillman \& Somero 2000, Stillman 2002). Upper thermal limits were reflected in Arrhenius break points in the thermal response of cardiac activity. The warmest adapted species displayed the lowest ability to further elevate its thermal limits, and will thus be prone to local extinction and pole-ward shifts in geographical distribution upon further warming. The reason for this pattern is that the warmest adapted species lives close to the upper thermal limits of the genus, in similar ways, as the warmest adapted population of eelpout or cod lives close to the upper or lower thermal limits of the respective species (see above).

The data available for cod strongly suggest that the thermal window of the north-eastern Arctic population is shifted to the cold side of the temperature range when compared to cod from the North Sea. Sensitivity of the Arctic population to warming is higher than in North Sea cod (Zittier et al. unpubl. obs.). Furthermore, available data for invertebrates and fish suggest that the shift of a wide window of thermal tolerance to colder temperatures goes hand in hand with a rise in energy turnover (Sommer \& Pörtner 2002, Fischer 2003, Lucassen et al. 2006, Wittmann et al. 2008, T. Fischer et al. unpubl. data). During adaptation to cold but unstable temperatures (both seasonal and latitudinal cold), eurytherms thus experience higher costs associated with metabolic cold adaptation (Pörtner et al. 2001, Pörtner 2002a,b, 2004, Sommer \& Pörtner 2002, 2004, Sokolova \& Pörtner 2003; for cod: Fischer 2003, Lannig et al. 2003, T. Fischer et al. unpubl. data). This pattern may reflect a key trade-off in eurythermal cold adaptation and may explain why thermal windows are set as narrow as possible in the cold. This occurs for the sake of energy savings, as found especially in Antarctic marine stenotherms (Pörtner 2006). As a correlate of eurythermal cold adaptation, the capacity to enhance aerobic enzyme activities and capacities of mitochondrial respiration during cold acclimation is largely enhanced in sub-Arctic populations of invertebrates and fish (Sommer \& Pörtner 2002, 2004, Lannig et al. 2003, Lucassen et al. 2006, Fischer et al. unpubl. data). The observation that NEAC display higher capacities of aerobic enzymes in the cold than NSC provides clear evidence for a genetic basis of cold acclimation capacity in the northern cod populations (Fig. 5).

In contrast to the patterns seen in cold-adapted eurytherms, it is now well established that the narrow thermal tolerance windows seen in some Antarctic marine ectotherms go hand in hand with low standard metabolic rates (SMR). These are paralleled by low mitochondrial capacities, but extremely high mitochondrial densities in aerobic tissues like red muscle as seen in notothenioids (Johnston et al. 1998, Clarke \& Johnston 1999, Peck \& Conway 2000, Pörtner et al. 2000). As indicated above, selection for energy savings at the whole organism level may be a key driving force in the climate-dependent evolution of narrow thermal win- 
dows in the cold and the resulting sensitivity to climate change (Pörtner 2006).

The cost of eurythermal cold adaptation is associated with elevated oxygen consumption rates caused by high proton leakage rates across mitochondrial membranes. These rates were elevated due to higher mitochondrial densities and capacities in the cold. Proton leakage rates may be high due to the specific enrichment of polyunsaturated fatty acids in membranes of cold-adapted eurytherms (cf. Pörtner 2004). In addition, enhanced ion movements (leakage) across cellular membranes may need to be compensated for by elevated densities and activities of ion exchange mechanisms (Pörtner et al. 1998). As an explanation, the costs of cold adaptation may be high in eurytherms because they make use of their mitochondria over the widest possible range of short-term temperature fluctuations. As a precondition, the metabolic increment elicited by rising temperature must be kept small in order to maintain aerobic scope. This minimizes the degree to which temperature-dependent kinetic barriers like high activation enthalpies can be established (for review see Pörtner et al. 2000, 2005a,b). In contrast to cold-adapted stenotherms, eurytherms may therefore choose to minimize mitochondrial densities and maximize their ATP synthesis capacities instead in order to balance the cold-induced rise in baseline metabolic costs. In principle, these pressures and con- straints in cold adaptation are similar in adults and juveniles, but may be felt especially by juvenile life stages, due to their elevated mitochondrial densities at small body size. The respective lifestyle consequences are thus exacerbated at the larval stages (see below).

\section{FUNCTIONAL CONSEQUENCES OF THERMAL ADAPTATION: LINKING PHYSIOLOGY AND ECOLOGY}

The contrasting physiological patterns of thermal tolerance between stenotherms and eurytherms were suggested to include energetic and lifestyle consequences depending on the width and location of the thermal tolerance window on the temperature scale (Pörtner 2002b, Pörtner et al. 2005a,b). Trade-offs in cellular and organismic energy budgets likely result from temperaturedependent adjustments of metabolic capacities (e.g. Guderley 1998) and associated costs (Pörtner et al. 1998), as well as associated changes in the pathways of energy allocation. The high SMRs found in cold-adapted and cold-acclimated eurytherms extend to enhanced capacities of ventilation and circulation. This will be a precondition for widened windows of thermal tolerance, and, as a consequence, may support cold-compensated metabolic scopes and performance levels (Pörtner 2002b, 2004). However, the ecological benefits of a 'cold-compensated' metabolic rate remain unclear, since cost enhancements need to be covered by higher foraging activity and food uptake. In fact, elevated SMRs in eurytherms adapted to cold climates in a latitudinal cline may be disadvantageous, as they may occur at the expense of growth performance and fecundity. Regardless of reproduction strategy there is in fact lower fecundity in both cod Gadus morhua and eelpout Zoarces viviparus at Arctic to subArctic latitudes (Pörtner et al. 2001). Growth maxima were also found to be lower in NEAC than in southern cod populations (Fig. 6; cf. Svasand et al. 1996, Pörtner et al. 2001), including NSC, despite similar temperature optima. Accordingly, elevated SMRs at the expense of growth (and possibly fecundity) may be selected for by climate variability (cf. Pörtner 2004, 2006).

Growth is a complex process subject to controls and limitations at several levels of biological organisation. Protein synthesis is the key cellular process underlying growth, and the ques- 
tion arises whether there are temperature-related limitations in protein synthesis. It was hypothesized that the cost of protein synthesis is influenced by temperature, with higher energy costs in the cold due to the cost of RNA synthesis (e.g. Marsh et al. 2001; reviewed by Fraser \& Rogers 2007). A recent analysis of the ATP cost of protein synthesis in temperate and polar pectinids demonstrated that the stoichiometric cost of protein synthesis remains unchanged regardless of temperature (Storch \& Pörtner 2003). Elevated tissue RNA levels have typically been found in cold-acclimated tissues and have been associated with higher energy cost due to the cost of RNA synthesis. They might, however, reflect steady state levels, which rise at low and decrease at warm temperatures, at no significant cost (Storch et al. 2005). High steady state RNA levels in the cold would support translation and, thus, protein synthesis. In addition, the functional capacity of the RNA translation apparatus is cold compensated in polar invertebrates and fishes, which is indicated by high translational capacities at low temperatures (Storch et al. 2003, 2005). These findings suggest enhanced func-

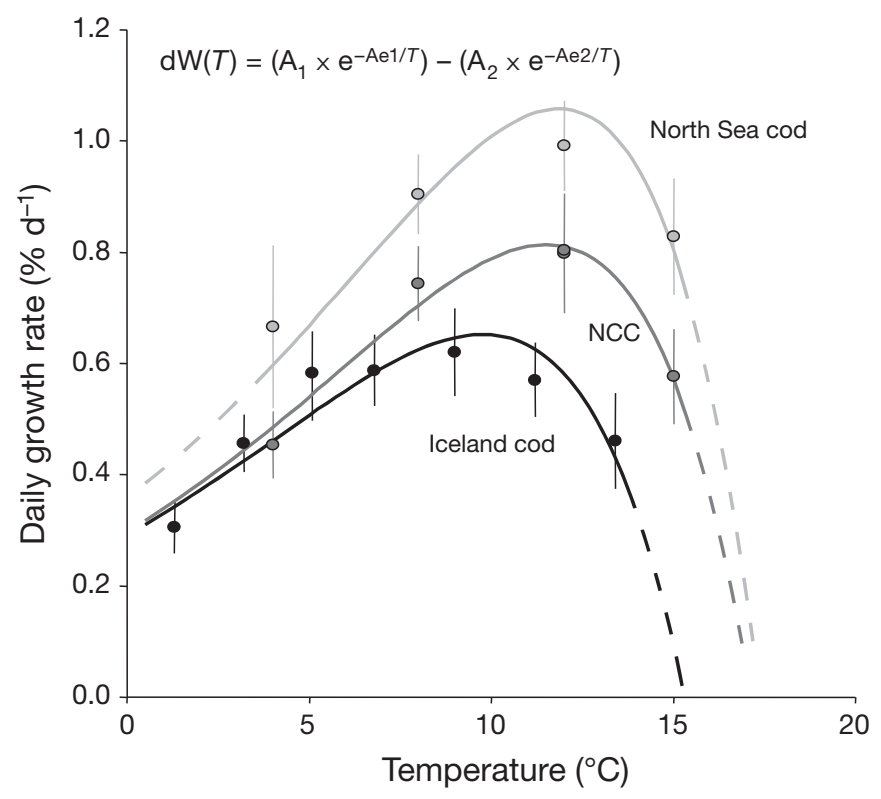

Fig. 6. Gadus morhua. Temperature-dependent growth in juvenile North Sea (NSC) versus Norwegian coastal cod (NCC) and Iceland cod according to data for NSC and NCC by Pörtner et al. (2001) and for Iceland cod by Björnsson et al. (2001), all fitted to the equation: $d L(T)=F_{1}(T)+F_{2}(T)$, where $d L(T)$ represents the daily length depending on temperature at maximum food supply. The first term $F_{1}(T)=A_{1} \times \mathrm{e}^{B 1 \times T}+C_{1}$ represents the kinetic stimulation of processes supporting growth performance capacity depending on temperature. The second term $F_{2}(T)=$ $A_{2} \times \mathrm{e}^{B 2 \times T}+C_{2}$ represents the processes limiting aerobic capacity (Fig. 2; Pörtner \& Knust 2007) and thus growth capacity (cf. Fig. 7). For all 3 populations, highest growth rates were found between 10 and $12^{\circ} \mathrm{C}$, with maximum rates in cod from the North Sea and lowest rates in sub-Arctic cod tional capacities of the growth machinery at maintained cost efficiency in cold-adapted polar ectotherms, in line with a trend to maximize growth performance at unchanged metabolic costs. Protein synthesis capacity is, thus, not limiting growth at low temperatures. Growth limitation rather results from cellular processes competing for limited energy or from low energy turnover rates as outlined above. Growth limitation may also result from elevated rates of protein turnover due to elevated rates of protein damage at cold temperatures. Rates of damage may be elevated due to trade-offs between enhanced protein flexibility required for function at cold temperature and the associated loss in stability (Fields 2001). Elevated levels of ubiquitin-bound proteins have, in fact, been found and interpreted as indicators of enhanced protein damage due to instability in coldadapted Antarctic notothenioids (Todgham et al. 2007). Alternatively and as with elevated RNA levels, enhanced levels of ubiquitin-bound proteins in the cold may rather reflect cold-adjusted steady state levels at limited extra cost.

Finally, the characteristics of oxygen-limited thermal tolerance and associated trade-offs in thermal adaptation provide an explanation of how ectotherms are able to escape from the cost of cold adaptation through a narrowing of thermal windows, or their seasonal shifts, for the benefit of enhanced growth, reproductive performance and fitness (Fig. 7). The aerobic performance maxima of animals, which should include the availability of aerobic energy for growth, reproductive performance, or fitness in general including exercise capacity, are found close to upper pejus temperatures (Fig. 3; Pörtner et al. 2004, 2005a). As a note of caution this statement is valid for fully acclimated animals such as those growing at a specific temperature. Very little is known about acute thermal windows and the associated temperature dependence of functional properties.

Limitations in aerobic capacity and in associated energy allocation towards lower and higher temperature extremes may reduce the exploitation of protein synthesis capacity. Maximum exploitation likely occurs at upper pejus temperatures, when the fraction of baseline metabolic costs in total aerobic scope and, thus, the level of competition by other processes for the available energy are minimal. This is illustrated by the finding of lowest cellular costs at optimum growth in the Antarctic eelpout (Fig. 8). Accordingly, studies of energy allocation should include the investigation of regulatory mechanisms involved in setting the fraction of the energy budget allocated to growth and to other components of SMR (cf. Wieser 1994).

These considerations are initially counter-intuitive, since an increase in SMR implies enhanced energy production by metabolism and might, therefore, indicate enhanced energy availability to growth. However, 

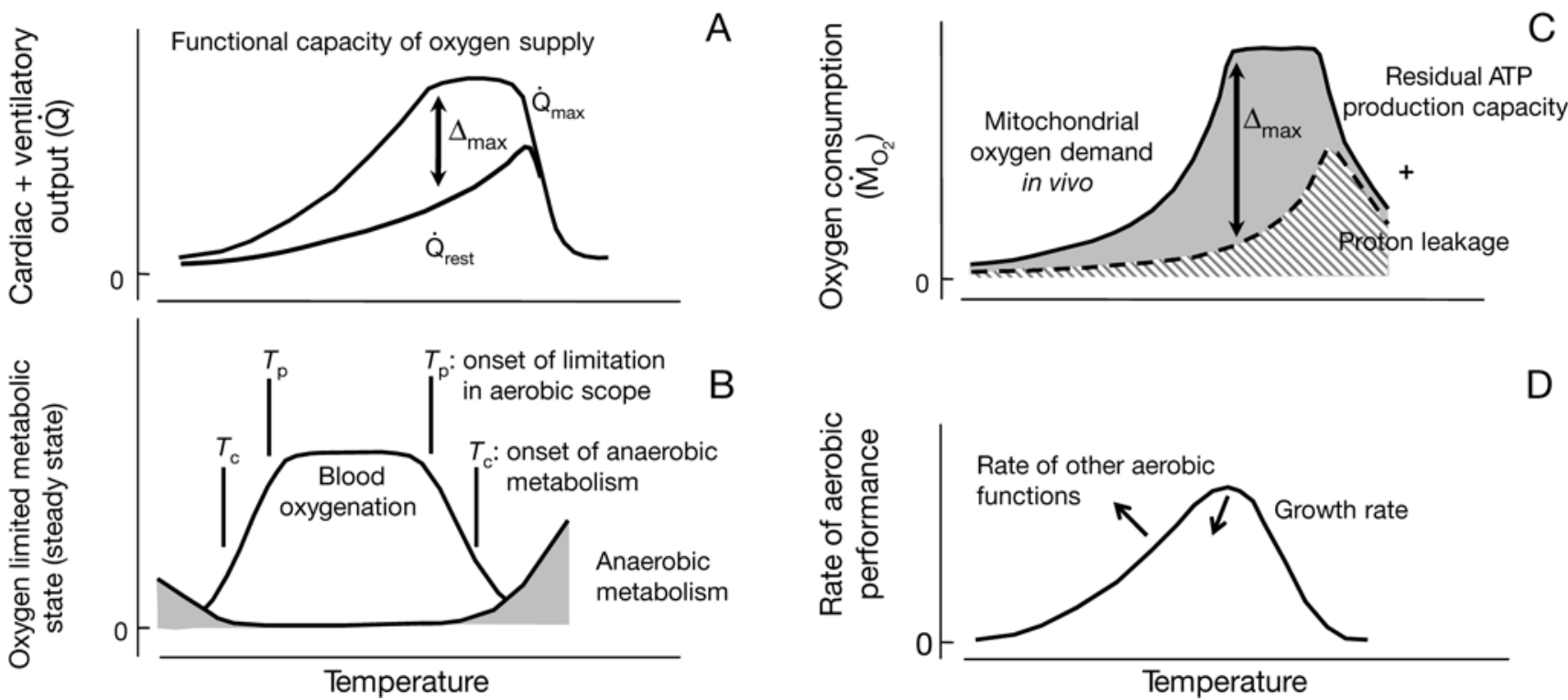

C

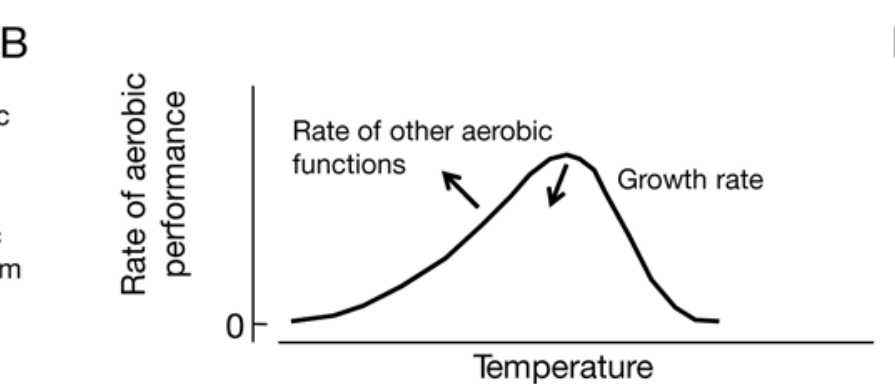

Fig. 7. Schematic model of oxygen-limited thermal tolerance and aerobic performance capacity in fish and other metazoans (modified after Pörtner et al. 2004). Oxygen availability is set by the capacity of oxygen supply mechanisms. Functional reserves in oxygen supply (A) result as combined ventilatory and cardiac output $(\dot{Q})$ and are maximum at the upper pejus temperature $T_{\mathrm{p}}$. Aerobic scope becomes thermally limited towards colder and warmer temperatures (B). Maximum scope ( $\left.\Delta_{\max }\right)$ between resting and maximum output in oxygen supply is likely correlated with the one in mitochondrial ATP generation such that the functional capacity of the (ventilatory and circulatory) muscles is co-defined by the capacity of mitochondria to produce ATP. ATP production capacity in vivo is limited by oxygen supply (C). This limitation is exacerbated by the temperature-dependent rise in baseline oxygen demand associated with the cost of mitochondrial proton leakage. The respective fraction of oxygen turnover is no longer available to ATP formation. Low ATP formation capacity in the cold and high proton leakage in the warm contribute to insufficient oxygen supply, loss of aerobic scope and, finally, transition to anaerobic metabolism (B). Maximum scope in ATP generation at the upper $T_{\mathrm{p}}$ not only supports maximum capacity of organismic oxygen supply by circulatory and ventilatory muscles, but also an asymmetric performance curve of the whole organism (D after Angilletta et al. 2002), with optimal performance (e.g. growth, exercise) again expected at the upper pejus temperature $T_{\mathrm{p}}$. Here, functions are supported by both high temperatures and optimum oxygen supply in relation to baseline oxygen demand. As a trade-off in eurythermal cold adaptation (e.g. with upper limits constant, lower limits shifting to colder temperatures), standard metabolism and, in consequence, other aerobic functions like exercise capacity may increase in the cold (Pörtner 2002b), while temperature-specific growth performance is reduced, likely due to enhanced mitochondrial proton leakage and the associated shift in energy budget (Pörtner et al. 2001). More recent data suggest modifying this hypothesis in that exercise capacity is at least maintained (Lurman et al. 2007) and growth capacity decreases in cold-adapted cod populations (Fig. 6). The contrasting patterns of exercise capacity versus those in growth rate are indicated by arrows in Panel D

across phyla, this may only be realized at very high levels of energy turnover, as seen in cephalopods or mammals (cf. Pörtner 2004). In the range of SMRs seen in most fish and invertebrate ectotherms and especially at low temperatures, a comparatively high SMR apparently reflects high maintenance costs covered at the expense of growth (Fig. 6). The results obtained in different cod populations are thus in line with those obtained earlier within single invertebrate species, where the primary physiological basis of an increase in production is a reduction of baseline energy expenditure per unit of growth (Hawkins et al. 1986, 1989, Hawkins \& Day 1996). This clearly indicates that enhanced growth efficiency is required for high growth rates in most ectotherms and cannot be compensated for by a straightforward increase in feeding and associated processes.
These considerations may also support interpretation of reproductive patterns as observed in NEAC and their energetic background. These cod migrate south to spawn close to the Lofoten Islands at somewhat higher temperatures than they usually find in the Barents Sea. While the evolution of this strategy may well be associated with food availability during spring blooms (e.g. Brander 1994, Kjesbu \& Witthames 2007), Fig. 1 and the previous discussion suggest that they may also do this for the sake of improved energy allocation to reproductive performance as well as faster larval development. Interestingly, these cod display elevated rates of standard metabolism at low temperature, when compared to their cold-acclimated conspecifics from the North Sea (Pörtner 2002a, Fischer 2003, T. Fischer et al. unpubl. data), but are able to acclimate to elevated temperatures like $10^{\circ} \mathrm{C}$ and, 


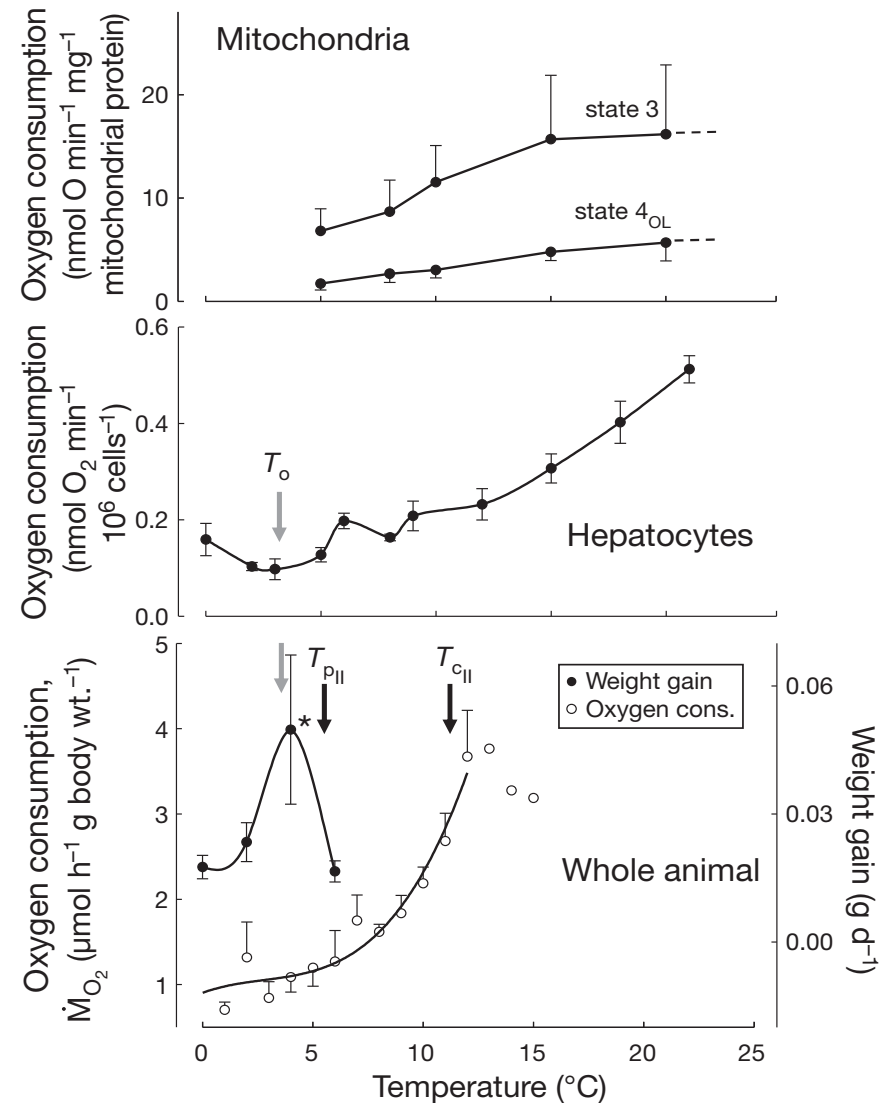

Fig. 8. Pachycara brachycephalum. Growth patterns within the thermal window of the Antarctic eelpout, which are characterized by an exponential rise in whole animal oxygen consumption (lower panel). Wider windows of mitochondrial (reflected in state 3 respiration, i.e. ATP synthesis capacity, and state $4_{\mathrm{OL}}$ respiration, i.e. proton leakage rates) and cellular (than whole animal) thermal tolerance (for all preparations animals were acclimated to $0^{\circ} \mathrm{C}$ ) reflect the highest thermal sensitivity at the whole organism level. An even narrower window results for growth, with an optimum rate (at $T_{\mathrm{o}}$ ) at lowest cellular costs (after Mark et al. 2002, 2005, Lannig et al. 2005, Brodte et al. 2006). ${ }^{*}$ Significant growth increment

most importantly, to reduce their level of standard metabolic rate to levels similar to those in North Sea cod at $10^{\circ} \mathrm{C}$. In general, reversal of seasonal metabolic cold adaptation typifies summer metabolic rates in temperate eurytherms (e.g. Van Dijk et al. 1999) and indicates reduced baseline energy costs at elevated temperature. By adopting the same strategy through southward migration and spawning, Barents Sea cod (NEAC) may enhance energy allocation to reproductive output. Furthermore, exposure of the larvae to warmer waters may alleviate the functional constraints caused by cold adaptation, which are felt especially at small body size (see below, Pörtner et al. 2005a). In general, eurythermal species populations at high latitudes may be able to exploit efficient summer metabolic rates at elevated temperatures and, thereby, escape the performance decrements associated with enhanced costs of cold adaptation. Future work will have to identify and quantify the mechanistic relationships between SMR and growth in those species with maximized summer growth.

These patterns and considerations also support an understanding of the contrasting features seen in Antarctic stenotherms, which live in stable cold climates. As a trade-off in permanent cold adaptation, these species likely have minimized the reduction of growth and reproductive performance at permanently low temperature by reducing the cost of cold adaptation. For the sake of maximized growth at permanently low temperature, they were forced to evolve an energy-efficient life in the cold at the expense of reduced motor capacity and narrow thermal tolerance windows. Once again these trends are seen especially in the larvae and juveniles of Antarctic notothenioid fish (Pörtner et al. 2005a,b, Pörtner 2006).

However, the trade-offs between growth rates and metabolic costs depicted here for cold-adapted, low- to moderate-activity fish and invertebrates may not easily explain all latitudinal growth patterns and energy allocation strategies observed. These patterns may be most clearly expressed in a latitudinal cline of thermal environments along temperate to northern European coasts of the eastern Atlantic. In contrast, growth capacity may not clearly differ between north-western Atlantic cod populations in a latitudinal cline (Purchase \& Brown 2001), possibly related to the respective temperature scenarios. The growth patterns discussed and interpreted here also contrast higher growth capacities in northern than in southern populations of (North American) silverside Menidia menidia (Yamahira \& Conover 2002). In this case, high growth capacity was suggested to compensate for the short growing season at high latitudes. This strategy is not apparently associated with different routine metabolic rates (Billerbeck et al. 2000). For a closer comparison and potential explanation of these contrasting patterns with respect to trade-offs in thermal adaptation and energy allocation, temperature variability, as well as the metabolic and energetic background, in relation to climate variability of specific environments require detailed investigation. This requires not only consideration of temperature means and variability (Pörtner et al. 2001, 2005a), but also of potential seasonal resource limitations (e.g. Hurst \& Conover 2002).

\section{WIDER ECOLOGICAL IMPLICATIONS}

The physiology of species and population-specific thermal windows may also explain higher level phenomena in marine ecosystems. The northward shift in 
the distributions of some fish species (including cod) currently observed in the North Sea (Perry et al. 2005) not only reflects the limited ability of species to adjust the thermal window to ambient conditions by adaptation (see above). They also reflect that thermal windows likely differ between species in an ecosystem, associated with different distribution ranges, and, accordingly, different thermal sensitivities and thus distribution shifts observed for various species (Perry et al. 2005). Finally, changing species composition and interactions result. As a prominent example of the latter, the shift in copepod faunal composition from larger Calanus finmarchicus to smaller C. helgolandicus in the southern North Sea causes reduced food availability for Atlantic cod Gadus morhua and was seen as a major reason for the decrease in abundance of cod (Beaugrand et al. 2003). More recently, the distribution shifts of the 2 copepod species themselves proved to be largely determined by warming effects (Helaouët \& Beaugrand 2007), reflecting the different thermal windows of the 2 copepod species. In the light of the present data and earlier findings for Atlantic cod (Pörtner et al. 2001), warming effects on cod in the field will thus comprise both direct and indirect effects via the food chain. However, the indirect effects on cod build on direct physiological effects of warming on the 2 species of prey, due to their different thermal windows. In general, changes in food web composition may build on the patterns of thermal windows and associated performance capacities of the species involved.

The seasonal timing of events (phytoplankton blooms, zooplankton development, spawning events, fertilization and, in general, development of various interacting species) is also influenced by climate change and contributes to modulate ecosystem dynamics. In principle, such shifts in timing may be understood as an earlier/later entry of ambient temperature into species-specific thermal windows. Differences between thermal windows of interacting species may then cause a mismatch between previously matched processes. One example includes earlier seasonal development of zooplankton (Greve et al. 1996), which may no longer match the seasonal phytoplankton blooms as a food source (Cushing 1995). Such mismatches may occur due to differential shifts in the timing of processes within the same year or as a result of shifts during the previous year. In the North Sea the latter is exemplified by the delayed development of diatom blooms due to later grazing by zooplankton in the previous year (Wiltshire \& Manly 2004). Similarly, Kröncke \& Knust (1995) and Knust (1996) reported a clear relationship between seasonal development in the benthos and the condition factor of the nonmigratory flat fish species Limanda limanda. Ambient temperature entering thermal windows may also elicit seasonal migration, as seen among fishes in the Wadden Sea (Zijlstra 1978), and define the timing of such migration, as seen, for example, in the earlier migratory entry of squid Loligo forbesi into the North Sea (Sims et al. 2001). The different windows of individual species, reflected in differential thermal sensitivities and timings of ontogeny, productivity and migratory patterns, will accordingly influence species interactions at the ecosystem level. The resulting changes in species interactions represent crucial components of ecosystem responses to climate change (e.g. Winder \& Schindler 2004). This emphasizes once again the role of physiological limits and associated species-specific dimensions of the thermal niche in understanding climate effects on ecosystem functioning.

As already mentioned, different thermal windows of coexisting species may explain so-called regime shifts in ecosystems. As a recent example, the shift between colder regimes dominated by sardines and warmer years dominated by anchovies on the Pacific coast of Japan matches the different windows of temperaturedependent growth of the 2 species (Takasuka et al. 2007). Interestingly, in other areas like upwelling systems, anchovies are the fish to prefer the colder temperatures (Arntz 1986). For a more comprehensive understanding of such patterns, it must be considered that fluctuating food availability may modulate the optimal temperature of growth, as an indirect temperature effect mediated through the food web.

The generalized hypothesis emerges that constraints and trade-offs in adaptation to a specific climate regime will affect those organisms similarly that display similar tolerance windows. Contrasting responses or responses with different intensity (Perry et al. 2005) may develop in those cases, where thermal windows differ between the various species shaping an ecosystem. They may differ because species display different performance levels or cover different latitudinal ranges. These ranges may overlap such that warm- and coldadapted organisms coexist in the same ecosystem. The southern North Sea represents a transition zone between cold-adapted boreal fauna and faunal elements from southern areas. It is, therefore, a good example for seasonal shifts in the fish community and for temporal changes in species composition due to climatic events like hot summers and cold or warm winters.

The physiological background as elaborated in previous sections may reflect the potential underpinning of ecological processes beyond those operative within individual species. These relationships thus require further integrated ecological and physiological investigations, including those of between-species interactions. As with the establishment of the concept of oxygen-limited thermal tolerance (Pörtner 2001, 2002a) studies across various phyla will be required to 
analyse the general validity of the principle interdependence of physiological and ecological processes. These studies should investigate and test the emerging conceptual understanding of how the various levels of biological organisation are intertwined and how they exert their specific role in defining the thermal tolerance window of a species, in relation to the temperature fluctuations and range in its natural environment (Fig. 9).

\section{CONCLUSIONS}

Our current knowledge of the relationships between climate forcing and species (or ecosystem) performance is mainly based on statistical analyses. The physiological information available on cod Gadus morhua and eelpout Zoarces viviparus from various climate regimes provides some understanding of how changing climate conditions affect survival and fitness of species in their natural environment. Current knowledge also provides access to the interdependence of climate conditions, the levels of eurythermy and associated energy turnover, as well as differing performance and fitness characteristics among populations. This understanding will lead to testable hypotheses concerning the causal relationships between food availability, fitness of individuals (condition, fecundity) and the development of populations (recruitment/mortality) under different climate conditions (water temperature). This is also true for the analysis of between-species interactions, food chain composition and, ultimately, biodiversity. The present study emphasizes various aspects of where the roles of match-mismatch phenomena at the organismal level (oxygen limitation and performance levels in relation to temperature-dependent energetics) may relate to those at the ecological level and how these patterns may depend on the role of the physiological adaptation potential of individuals in the population.

Among the specific examples discussed, eelpout populations in the German Wadden Sea are currently experiencing a population decline due to the direct effect of summer extreme temperatures on aerobic performance, which ultimately determines the fitness of individual specimens. The situation is more complex for cod in the North Sea, where population decline may partly be supported by the direct effects of warming on the reproductive performance of the spawning stock in spring. This effect may combine with reduced food availability for juveniles through the heatinduced loss of larger copepod species. At the same time, the Arctic populations of Atlantic cod are expanding further north, presently supported, not only by the warming trend, but also by a higher cold acclimation capacity than found in southern populations.

Acknowledgements. This paper partly builds on analyses started within the ELOISE project: 'Effects of climate induced temperature change on marine coastal fishes (CLICOFI)', funded by the European Union program 'Climate and environment', Contract No. ENV4-CT97-0596.

\section{LITERATURE CITED}

Angilletta MJ, Niewiarowski PH, Navas CA (2002) The evolution of thermal physiology in ectotherms. J Therm Biol 27: $249-268$

Armonies W, Herre E, Sturm M (2001) Effects of the severe winter 1995/96 on the benthic macrofauna of the Wadden Sea and the coastal North Sea near the Island of Sylt. Helgol Mar Res 55:170-175

Arntz WE (1986) The two faces of El Niño 1982-83. Arch Fish Mar Res 31:1-46

Bakun A (1996) Patterns in the ocean-ocean processes and marine population dynamics. California Sea Grant College System, La Jolla, CA

Bartsch J, Knust R (1994a) Predicting the dispersion of sprat larvae (Sprattus sprattus (L.)) in the German Bight. Fish Oceanogr 3:292-296 
Bartsch J, Knust R (1994b) Simulating the dispersion of vertically migrating sprat larvae (Sprattus sprattus (L.)) in the German Bight with a circulation and transport model system. Fish Oceanogr 3:92-105

Beamish RJ (ed) (1995) Climate change and northern fish populations. Can Spec Publ Fish Aquat Sci 121:1-739

Beaugrand G, Brander KM, Lindley JA, Souissi S, Reid PC (2003) Plankton effect on cod recruitment in the North Sea. Nature 426:661-664

Beentjes MP, Renwick JA (2001) The relationship between red cod, Pseudophycis bachus, recruitment and environmental variables in New Zealand. Environ Biol Fishes 61: 315-328

Billerbeck JM, Schultz ET, Conover DO (2000) Adaptive variation in energy acquisition and allocation among latitudinal populations of the Atlantic silverside. Oecologia 122: 210-219

Björnsson B, Steinarsson A (2002) The food-unlimited growth rate of Atlantic cod (Gadus morhua). Can J Fish Aquat Sci 59:494-502

Björnsson B, Steinarsson A, Oddgeirsson M (2001) Effects of size on optimal temperature for growth and feed conversion of immature cod (Gadus morhua L.). ICES J Mar Sci 58:29-38

Brander KM (1994) The location and timing of cod spawning around the British Isles. ICES J Mar Sci 51:71-89

Brander K, Mohn R (2004) Effect of the North Atlantic Oscillation on recruitment of Atlantic cod (Gadus morhua). Can J Fish Aquat Sci 61:1558-1564

Brix O, Foras E, Strand I (1998) Genetic variation and functional properties of Atlantic cod hemoglobins: introducing a modified tonometric method for studying fragile hemoglobins. Comp Biochem Physiol 119A:575-583

Brix O, Thorkildsen S, Colosimo A (2004) Temperature acclimation modulates the oxygen binding properties of the Atlantic cod (Gadus morhua) genotypes-HBI*1/1, $\mathrm{HbI}^{*} 1 / 2$, and $\mathrm{HbI}^{*} 2 / 2$ - changing the concentrations of their major haemoglobin components (results from growth studies at different temperatures). Comp Biochem Physiol 138A:241-251

Brodte E, Knust R, Pörtner HO (2006) Temperature dependent energy allocation to growth in Antarctic and boreal eelpout (Zoarcidae). Polar Biol 30:95-107

Clarke A, Johnston NM (1999) Scaling of metabolic rate with body mass and temperature in teleost fish. J Anim Ecol 68:893-905

Colosimo A, Giuliani A, Maranghi F, Brix O and others (2003) Physiological and genetical adaptation to temperature in fish populations. Cont Shelf Res 23:1919-1928

Cushing DH (1975) Marine ecology and fisheries. Cambridge University Press, Cambridge

Cushing DH (1982) Climate and fisheries. Academic Press, London

Cushing DH (1995) The long-term relationship between zooplankton and fish. ICES J Mar Sci 52:611-626

Dippner JW, Ottersen G (2001) Cod and climate variability in the Barents Sea. Clim Res 17:73-82

Drinkwater KF, Beaugrand G, Kaeriyama M, Kim S and others (in press) On the mechanisms linking climate to ecosystem changes. J Mar Syst

Farrell AP (2002) Cardiorespiratory performance in salmonids during exercise at high temperature: insights into cardiovascular design limitations in fishes. Comp Biochem Physiol 132A:797-810

Fields P (2001) Protein function at thermal extremes: balancing stability and flexibility. Comp Biochem Physiol 129A: $417-431$
Finney BP, Gregory-Eaves I, Douglas MSV, Smol JP (2002) Fisheries productivity in the northeastern Pacific Ocean over the past 2, 200 years. Nature 416:729-733

Fischer T (2003) The effects of climate induced temperature changes on cod (Gadus morhua L.): linking ecological and physiological investigations. Rep Polar Mar Res 454:1-101

Fonds M, Jaworski A, Iedema A, Puyl PVD (1989) Metabolism, food consumption, growth and food conversion of shorthorn sculpin (Myoxocephalus scorpius) and eelpout (Zoarces viviparus). ICES (Demersal Fish Comm) G: 31989:1-10

Fraser KPP, Rogers A (2007) Protein metabolism in marine animals: the underlying mechanism of growth. Adv Mar Biol 52:267-362

Frederich M, Pörtner HO (2000) Oxygen limitation of thermal tolerance defined by cardiac and ventilatory performance in the spider crab Maja squinado. Am J Physiol 279: R1531-R1538

Greve W, Reiners F, Nast J (1996) Biocoenotic changes of the zooplankton in German Bight: the possible effects of eutrophication and climate. ICES J Mar Sci 53:951-956

Guderley H (1998) Temperature and growth rates as modulators of the metabolic capacities of fish muscle. In: Pörtner HO, Playle R (eds) Cold ocean physiology. Cambridge University Press, Cambridge, p 58-87

Hawkins AJS, Day AJ (1996) The metabolic basis of genetic differences in growth efficiency among marine animals. J Exp Mar Biol Ecol 203:93-115

Hawkins AJS, Bayne BL, Day AJ (1986) Protein turnover, physiological energetics and heterozygosity in the blue mussel, Mytilus edulis: the basis of variable age-specific growth. Proc R Soc Lond 229B:161-176

Hawkins AJS, Widdows J, Bayne BL (1989) The relevance of whole-body protein metabolism to measured costs of maintenance and growth in Mytilus edulis. Physiol Zool 62:745-763

Heath AG, Hughes GM (1973) Cardiovascular and respiratory changes during heat stress in rainbow trout (Salmo gairdneri). J Exp Biol 59:323-338

Helaouët P, Beaugrand G (2007) Macroecological study of the niche of Calanus finmarchicus and C. helgolandicus in the North Atlantic Ocean and adjacent seas. Mar Ecol Prog Ser 345:147-165

Hochachka PW, Somero GN (2002) Biochemical adaptation: mechanism and process in physiological evolution. Oxford University Press, Oxford

Hummel H, Sommer A, Bogaards RH, Pörtner HO (1997) Variation in genetic traits of the lugworm Arenicola marina: temperature related expression of mitochondrial allozymes? Mar Ecol Prog Ser 159:189-195

Huntley B, Green RE, Collingham YC, Hill JK and others (2004) The performance of models relating species geographical distributions to climate is independent of trophic level. Ecol Lett 7:417-426

> Hurst TP, Conover DO (2002) Effects of temperature and salinity on survival of young-of-the-year Hudson River striped bass (Morone saxatilis): implications for optimal overwintering habitats. Can J Fish Aquat Sci 59:787-795

IPCC (Intergovernmental Panel on Climate Change) (2001) Third assessment report. Cambridge University Press, Cambridge

IPCC (2007) Fourth assessment report. Cambridge University Press, Cambridge

> Jensen MN (2003) Consensus on ecological impact remains elusive. Science 299:38

> Johnston IA, Calvo J, Guderley H, Fernandez D, Palmer L (1998) Latitudinal variation in the abundance and oxida- 
tive capacities of muscle mitochondria in perciform fishes. J Exp Biol 201:1-12

Kjesbu OS, Witthames PR (2007) Evolutionary pressure on reproductive strategies in flatfish and groundfish: relevant concepts and methodological advancements. J Sea Res 58: $23-34$

Kjesbu OS, Solemdal P, Bratland P, Fonn M (1996) Variation in annual egg production in individual captive Atlantic cod (Gadus morhua). Can J Fish Aquat Sci 53:610-620

Kjesbu OS, Witthames PR, Solemdal P, Walker MG (1998) Temporal variations in the fecundity of Arcto-Norwegian cod (Gadus morhua) in response to natural changes in food and temperature. J Sea Res 40:303-321

Knust R (1996) Food ecology of North Sea dab (Limanda limanda). Part 1: seasonal changes in food uptake and condition in the German Bight and on Dogger Bank. Arch Fish Mar Res 44:1-12

Kröncke I, Knust R (1995) The Dogger Bank: a special ecological region in the Central North Sea. Helgol Meeresforsch 49:335-353

Kröncke I, Dippner JW, Heyen H, Zeiss B (1998) Long-term changes in macrofaunal communities off Norderney (East Frisia, Germany) in relation to climate variability. Mar Ecol Prog Ser 167:25-36

Lannig G, Eckerle L, Serendero I, Sartoris FJ and others (2003) Temperature adaptation in eurythermal cod (Gadus morhua): a comparison of mitochondrial enzyme capacities in boreal and Arctic populations. Mar Biol 142:589-599

Lannig G, Bock C, Sartoris FJ, Pörtner HO (2004) Oxygen limitation of thermal tolerance in cod, Gadus morhua L., studied by non-invasive NMR techniques and on-line venous oxygen monitoring. Am J Physiol 287:R902-R910

Lannig G, Storch D, Pörtner HO (2005) Aerobic mitochondrial capacities in Antarctic and temperate eelpout (Zoarcidae) subjected to warm versus cold acclimation. Polar Biol 28: 575-584

- Lucassen M, Koschnick N, Eckerle LG, Pörtner HO (2006) Mitochondrial mechanisms of cold adaptation in cod (Gadus morhua) populations from different climatic zones. J Exp Biol 209:2462-2471

> Lurman GJ, Bock C, Pörtner HO (2007) An examination of the metabolic processes underpinning critical swimming in Atlantic cod (Gadus morhua L.) using in vivo ${ }^{31} \mathrm{P}-\mathrm{NMR}$ spectroscopy. J Exp Biol 210:3749-3756

Mark FC, Bock C, Pörtner HO (2002) Oxygen-limited thermal tolerance in Antarctic fish investigated by MRI and ${ }^{31}$ P-MRS. Am J Physiol Regul Integr Comp Physiol 283: R1254-R1262

Mark FC, Hirse T, Pörtner HO (2005) Thermal sensitivity of cellular energy budgets in Antarctic fish hepatocytes. Polar Biol 28:805-814

- Marsh AG, Maxson REJ, Manahan DT (2001) High macromolecular synthesis with low metabolic cost in Antarctic sea urchin embryos. Science 291:1950-1952

Marshall CT, Kjesbu OS, Yaragina NA, Solemdal P, Ulltang O (1998) Is spawner biomass a sensitive measure of the reproductive and recruitment potential of Northeast Arctic cod? Can J Fish Aquat Sci 55:1766-1783

Marshall CT, Yaragina NA, Adlandsvik B, Dolgov AV (2000) Reconstructing the stock-recruitment relationship for Northeast Arctic cod using a bioenergetic index of reproductive potential. Can J Fish Aquat Sci 57:2433-2442

Meier HEM (2002) Regional ocean climate simulations with a 3D ice-ocean model for the Baltic Sea. Part 1: model experiments and results for temperature and salinity. Clim Dyn 19:237-253

Mukhina NV, Marshall CT, Yaragina NA (2003) Tracking the signal in year-class strength of Northeast Arctic cod through multiple survey estimates of egg, larval and juvenile abundance. J Sea Res 50:57-75

> Nielsen EE, Hansen MM, Schmidt C, Medrup D, Grønkjær P (2001) Population of origin of Atlantic cod. Nature 413:272

> O'Brien CM, Fox CJ, Planque B, Casey J (2000) Climate variability and North Sea cod. Nature 404:142

Otterlei E, Nyhammer G, Folkvord A, Stefansson SO (1999) Temperature- and size-dependent growth of larval and early juvenile Atlantic cod (Gadus morhua): a comparative study of Norwegian coastal cod and northeast Arctic cod. Can J Fish Aquat Sci 56:2099-2111

$>$ Ottersen G, Sundby S (1995) Effects of temperature, wind and spawning stock biomass on recruitment of ArctoNorwegian cod. Fish Oceanogr 4:278-292

> Ottersen G, Hjermann DO, Stenseth NC (2006) Changes in spawning stock structure strengthen the link between climate and recruitment in a heavily fished cod (Gadus morhua) stock. Fish Oceanogr 15:230-243

> Parmesan C, Yohe G (2003) A globally coherent fingerprint of climate change impacts across natural systems. Nature 421:37-42

> Parsons LS, Lear WH (2001) Climate variability marine ecosystems impacts: a North Atlantic perspective. Prog Oceanogr 49:167-188

Peck LS, Conway LZ (2000) The myth of metabolic cold adaptation: oxygen consumption in stenothermal Antarctic bivalves. In: Harper E, Taylor JD, Crame JA (eds) Evolutionary biology of the Bivalvia. Special Publication 177, Geological Society, London, p 441-450

Pepin P, Orr DC, Anderson JT (1997) Time to hatch and larval size in relation to temperature and egg size in Atlantic cod (Gadus morhua). Can J Fish Aquat Sci 54(Suppl 1): $2-10$

Perry AL, Low PJ, Ellis JR, Reynolds JD (2005) Climate change and distribution shifts in marine fishes. Science 308:1912-1915

Planque B, Frédou T (1999) Temperature and the recruitment of Atlantic cod (Gadus morhua). Can J Fish Aquat Sci 56: 2069-2077

Pörtner HO (2001) Climate change and temperaturedependent biogeography: oxygen limitation of thermal tolerance in animals. Naturwissenschaften 88:137-146

Pörtner HO (2002a) Climate variations and the physiological basis of temperature dependent biogeography: systemic to molecular hierarchy of thermal tolerance in animals. Comp Biochem Physiol 132A:739-761

> Pörtner HO (2002b) Physiological basis of temperature dependent biogeography: tradeoffs in muscle design and performance in polar ectotherms. J Exp Biol 205:2217-2230

Pörtner HO (2004) Climate variability and the energetic pathways of evolution: the origin of endothermy in mammals and birds. Physiol Biochem Zool 77:959-981

> Pörtner HO (2006) Climate dependent evolution of Antarctic ectotherms: an integrative analysis (EASIZ, SCAR). DeepSea Res II 53:1071-1104

> Pörtner HO, Knust R (2007) Climate change affects marine fishes through the oxygen limitation of thermal tolerance. Science 315:95-97

Pörtner HO, Hardewig I, Sartoris FJ, van Dijk PLM (1998) Energetic aspects of cold adaptation: critical temperatures in metabolic, ionic and acid-base regulation? In: Pörtner HO, Playle RC (eds) Cold ocean physiology. Cambridge University Press, Cambridge, p 88-120

Pörtner HO, Van Dijk PLM, Hardewig I, Sommer A (2000) Levels of metabolic cold adaptation: tradeoffs in eurythermal and stenothermal ectotherms. In: Davison W, Williams 
CW (eds) Antarctic ecosystems: models for a wider understanding. Caxton Press, Christchurch, p 109-122

Pörtner HO, Berdal B, Blust R, Brix O and others (2001) Climate induced temperature effects on growth performance, fecundity and recruitment in marine fish: developing a hypothesis for cause and effect relationships in Atlantic cod (Gadus morhua) and common eelpout (Zoarces viviparus). Cont Shelf Res 21:1975-1997

Pörtner HO, Mark FC, Bock C (2004) Oxygen limited thermal tolerance in fish? Answers obtained by nuclear magnetic resonance techniques. Respir Physiol Neurobiol 141: 243-260

Pörtner HO, Lucassen M, Storch D (2005a) Metabolic biochemistry, an integrative view. In: Farrell AP, Steffensen JF (eds) The physiology of polar fishes. Fish Physiol 22: $79-154$

Pörtner HO, Storch D, Heilmayer O (2005b) Constraints and trade-offs in climate dependent adaptation: energy budgets and growth in a latitudinal cline. Sci Mar 69(Suppl 2): 271-285

> Purchase CF, Brown JA (2001) Stock-specific changes in growth rates, food conversion efficiencies, and energy allocation in response to temperature change in juvenile Atlantic cod. J Fish Biol 58:36-52

Root TL, Price JT, Hall KR, Schneider SH, Rosenzweig C, Pounds JA (2003) Fingerprints of global warming on wild animals and plants. Nature 421:57-60

Rothschild BJ (1986) Dynamics of marine fish populations. Harvard University Press, Cambridge, MA

> Roy K, Jablonski D, Valentine JW, Rosenberg G (1998) Marine latitudinal diversity gradient: tests of causal hypotheses. Proc Natl Acad Sci USA 95:3699-3702

Sartoris FJ, Bock C, Serendero I, Lannig G, Pörtner HO (2003) Temperature dependent changes in energy metabolism, intracellular $\mathrm{pH}$ and blood oxygen tension in the Atlantic cod, Gadus morhua. J Fish Biol 62:1239-1253

Sheppard C (2004) Sea surface temperature 1871-2099 in 14 cells around the United Kingdom. Mar Pollut Bull 49: $12-16$

Sims DW, Genner MJ, Southward AJ, Hawkins SJ (2001) Timing of squid migration reflects North Atlantic climate variability. Proc R Soc Lond B Biol Sci 268:2607-2611

Sirabella P, Giuliani A, Colosimo A, Dippner JW (2001) Breaking down the climate effects on cod recruitment by principal component analysis and canonical correlation. Mar Ecol Prog Ser 216:213-222

Sokolova IM, Pörtner HO (2003) Metabolic plasticity and critical temperatures for aerobic scope in a eurythermal marine invertebrate (Littorina saxatilis, Gastropoda: Littorinidae) from different latitudes. J Exp Biol 206: 195-207

Sommer AM, Pörtner HO (1999) Exposure of Arenicola marina (L.) to extreme temperatures: adaptive flexibility of a boreal and a subpolar population. Mar Ecol Prog Ser 181: 215-226

Sommer AM, Pörtner HO (2002) Metabolic cold adaptation in the lugworm Arenicola marina: comparison of a North Sea and a White Sea population. Mar Ecol Prog Ser 240: 171-182

Sommer AM, Pörtner HO (2004) Mitochondrial function in seasonal acclimatisation versus latitudinal adaptation to cold, in the lugworm Arenicola marina (L.). Physiol Biochem Zool 77:174-186

Sommer AM, Klein B, Pörtner HO (1997) Temperature induced anaerobiosis in two populations of the polychaete worm Arenicola marina. J Comp Physiol 167B:25-35

Southward AJ, Hawkins SJ, Burrows MT (1995) Seventy years' observations of changes in distribution and abundance of zooplankton and intertidal organisms in the western English Channel in relation to rising sea temperature. J Therm Biol 20:127-155

Stachowicz JJ, Terwin JR, Whitlatch RB, Osman RW (2002) Linking climate change and biological invasions: ocean warming facilitates non-indigenous species invasions. Proc Natl Acad Sci USA 99:15497-15500

Stenseth NC, Mysterud A (2002) Climate, changing phenology, and other life history traits: nonlinearity and matchmismatch to the environment. Proc Natl Acad Sci USA 99: 13379-13381

Stige LC, Ottersen G, Brander K, Chan KS, Stenseth NC (2006) Cod and climate: effect of the North Atlantic Oscillation on recruitment in the North Atlantic. Mar Ecol Prog Ser 325:227-241

Stillman JH (2002) Causes and consequences of thermal tolerance limits in rocky intertidal porcelain crabs, genus Petrolisthes. Integr Comp Biol 42:790-796

> Stillman JH, Somero GN (2000) A comparative analysis of the upper thermal tolerance limits of eastern Pacific porcelain crabs, genus Petrolisthes: influences of latitude, vertical zonation, acclimation, and phylogeny. Physiol Biochem Zool 73:200-208

Storch D, Pörtner HO (2003) The protein synthesis machinery operates at the same expense in eurythermal and cold stenothermal pectinids. Physiol Biochem Zool 76:28-40

Storch D, Heilmayer O, Hardewig I, Pörtner HO (2003) In vitro protein synthesis capacities in a cold stenothermal and a temperate eurythermal pectinid. J Comp Physiol [B] 173:611-620

> Storch D, Lannig G, Pörtner HO (2005) Temperature dependent protein synthesis capacities in Antarctic and temperate (North Sea) fish (Zoarcidae). J Exp Biol 208:2409-2420

Svasand T, Jorstad KE, Ottera H, Kjesbu OS (1996) Differences in growth performance between Arcto-Norwegian and Norwegian coastal cod reared under identical conditions. J Fish Biol 49:108-119

Takasuka A, Oozeki Y, Aoki I (2007) Optimal growth temperature hypothesis: Why do anchovy flourish and sardine collapse or vice versa under the same ocean regime? Can J Fish Aquat Sci 64:768-776

Takasuka A, Oozeki Y, Kubota H (2008) Multi-species regime shifts reflected in spawning temperature optima of small pelagic fish in the western North Pacific. Mar Ecol Prog Ser 360:211-217

Tiews K (1983) Über die Veränderungen im Auftreten von Fischen und Krebsen im Beifang der deutschen Garnelenfischerei während der Jahre 1954-1981. Arch FischWiss 34:1-156

Tiews K, Wienberg H (1990) Grundlagenmaterial zu '35Jahres-Trend (1954-1988) der Häufigkeit von 25 Fischund Krebstierarten an der deutschen Nordseeküste. Veröff Inst Küste Binnenfisch 103:1-64

Todgham AE, Hoaglund EA, Hofmann GE (2007) Is cold the new hot? Elevated ubiquitin-conjugated protein levels in tissues of Antarctic fish as evidence for cold-denaturation of proteins in vivo. J Comp Physiol (B) 177(8):857-866

Trippel EA, Morgan MJ, Frechet A, Rollet C and others (1997) Changes in age and length at sexual maturity of Northwest Atlantic cod, haddock and pollock stocks, 19721995. Can Tech Rep Fish Aquat Sci 2157(XII):1-132

> Ulltang O (1996) Stock assessment and biological knowledge: Can prediction uncertainty be reduced? ICES J Mar Sci 53:659-675

- Van Dijk PLM, Tesch C, Hardewig I, Pörtner HO (1999) Physiological disturbances at critically high temperatures: a com- 
parison between stenothermal antarctic and eurythermal temperate eelpouts (Zoarcidae). J Exp Biol 202:3611-3621 von Westernhagen H, Schnack D (2001) The effect of climate on fish populations. In: Lozán LL, Graßl H, Hupfer P (eds) Climate of the 21st century: changes and risks. Wissenschaftliche Auswertung, Hamburg, p 283-289

Whitehead PJP, Bauchot ML, Hureau JC, Nielsen J, Tortonese E (1994) Fishes of the north-eastern Atlantic and the Mediterranean, Vols I-III. United Nations Educational, Scientifics and Cultural Organisation, Paris

Wieser W (1994) Cost of growth in cells and organisms: general rules and comparative aspects. Biol Rev Camb Philos Soc 68:1-33

Wiltshire KH, Manly BFJ (2004) The warming trend at Helgoland Roads, North Sea: phytoplankton response. Helgol Mar Res 58:269-273

Winder M, Schindler DB (2004) Climate change uncouples

Submitted: October 18, 2007; Accepted: July 15, 2008 trophic interactions in an aquatic ecosystem. Ecology 85: $2100-2106$

Wittmann AC, Schröer M, Bock C, Steeger HU, Paul R, Pörtner HO (2008) Indicators of oxygen and capacity-limited thermal tolerance in the lugworm Arenicola marina. Clim Res 37:227-240

Yamahira K, Conover DO (2002) Intra- vs. interspecific latitudinal variation in growth: adaptation to temperature or length of the growing season? Ecology 83:1252-1262

Zakhartsev MV, De Wachter B, Sartoris FJ, Pörtner HO, Blust R (2003) Thermal physiology of the common eelpout (Zoarces viviparus). J Comp Physiol (B) 173: 365-378

Zijlstra JJ (1978) The function of the Wadden Sea for the members of its fauna. In: Dankers NMJA, Wolff WJ, Zijlstra JJ (eds) Fishes and fisheries of the Wadden Sea. Balkema, Rotterdam, p 1-10

Proofs received from author(s): September 29, 2008 